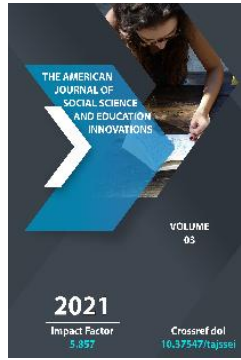

\title{
Socio-Psychological Mechanism Of Self-Identification
}

\author{
Turakhanov Ummatali Davlatovich \\ Senior Lecturer, Namangan State University, Uzbekistan
}

Journal Website:

http://usajournalshub.c

om/index,php/tajssei

Copyright: Original content from this work may be used under the terms of the creative commons attributes 4.0 licence.

\section{ABSTRACT}

Based on the theoretical and methodological foundations of self-identification, it is important not only to determine its essence and its relationship to other events close to it, but also to reveal its sociopsychological mechanism.

An analysis of the scientific literature on research problems shows that, first of all, self-determination is essentially a special process, a mental activity aimed at analyzing the external world, distinguishing its content and significance, generalizing the identified objects.

\section{KEYWORDS}

Psychodynamic,psychoanalytic approaches, internal struggles, conflicting positions, youth, elite, special orientation.

\section{INTRODUCTION}

Personality is governed by a system of ideas about the past, present, and future based on the construction of the way of life, the long- term regulation of human life. The inner world of man is in a state of constant contradictions, which manifest themselves in tensions. 
According to classical psychodynamic and psychoanalytic approaches, the source of such stress includes internal struggles, conflicting positions, and thoughts that are important to the person.

The results of research show that a person often does not understand their internal contradictions, but they cause a feeling of excessive anxiety related to other areas of their life activities and usually have a devastating effect on behavior. Such inconsistencies can only be remedied by comparing positions and making appropriate decisions. This approach helps to understand and distinguish the existing sociopsychological mechanisms that make changes in self-identification $[68,212]$.

In essence, the above situation reflects a procedural approach to the study of selfidentification, involving different concepts. One of them is the dynamic system and the period of development momentum.

The concept of a dynamic system encompasses existing features in the phenomenon of selfidentification, in particular their quantitative and qualitative changes as the emergence of new types of relationships between the individual and the world.

The concept of the moment of development is a specific stage of self-identification that reflects the stage that characterizes personality change.

Self-identification as a dynamic system is reflected in the concept of identification, which mainly refers to the movement of the individual, the mechanism of formation of his identity. The concept of identification represents the moment of action, the state achieved by the person in the process of identification [39, 99, 214, 232, etc.].

The essence of identification and identification is, on the one hand, their unity and, on the other hand, their contradiction.

Identification and identification are manifested by the fact that they are two relatively independent aspects and do not exist without each other, since they are the only process on the path of socialization of the individual. It is expedient that these two parties be regarded as a whole unit.

Identification A key feature in the identification process is the reflection of the moment. Identification as a process of moment and conflict does not exist without a moment apart from each other as units of development. It is not possible to identify with other individuals without identification.

Identification and identification is, first and foremost, the manifestation of selfidentification as a holistic socio-psychological phenomenon. Everyone is socialized through identification with society, which allows them to explore relevant social experiences.

Who is associated with the desire to identify a person with a group and his desire to isolate? A person's need for communication is different from his need for his personality. In society, only in communication with himself, he begins to understand more of his own judgments, his own conclusions. But in the later stages they are restricted, and then obstacles to the development of free individuality begin. Outdated forms of communities in which a person identifies himself must be changed and supplemented by processes and tools, concepts that open up new opportunities for 
the socialization of the individual. Observing the connections between the stages of development allows us to understand the dynamics of this process, and the specific features of the interrelationships between these stages include the placement of key ideas that make up the movement of selfidentification [84, 166, 197, 203].

The unit of identification and identification should only correspond to the level of identification as the ratio of the level of identification to the real value and the ratio of the value to the 'I'. For a person to develop, this process must be in a state of dynamic equilibrium. New conditions, which are constantly distinguished by the requirements and conditions, interests, capabilities, desires of the individual, are defined as the emergence of equilibrium. In this case, the individual seeks to achieve the balance required by the conditions of identification and identification harmonization within the framework of selfidentification $[95,195]$.

Self-identification is very important and crucial in shaping a person's unique characteristics. After all, it means the level of knowledge of a person's desires and capabilities, their integration into a particular society. In this context, self-determination manifests itself both simultaneously and as a value-motivating tool of society.

Socialization is a process in which selfdetermination begins in the early days of a person's life, and the person is constantly in a continuum that improves their relationships, their connections with the outside world.
Sources of socialization are family, educational institutions, literature, art, mass media and others.

In the process of primary socialization, family and environmental conditions are one of the factors influencing the formation of personality. The process of secondary socialization involves the participation of a person in the process of self-identification, which means that society has the opportunity to choose the types of social behavior. It is an opportunity to create an image of a person at will, based on moral and aesthetic values.

As the process of socialization progresses, the role of identification relative to other mechanisms (e.g., imitation) increases. Accordingly, the scope of personality concepts expands and changes as depth increases. From verbal registration to the professional group (at the stage of adaptation), the quality of conscious activity in accordance with the interests of this group, the acceptance of their goals and norms as their own, is positive. [198, 214].

AA Biryukov, Al Matveeva emphasize that selfidentification in society requires constant social assistance. A person cannot be human without other individuals because it is impossible to identify without society. The authors suggest that personal identification is the identification of a person's physical, psychological, or moral characteristics, his or her status, role traits, based on the individual's personal interests, in conjunction with the public. According to AA Biryukov, Al Matveeva, another type of social identification is the realization of the individual by uniting them into certain social categories (youth, elite, special orientation, industry), groups that do 
not have organizational boundaries, differ by some criteria. Its symptoms:

\section{Young;}

The situation in society;

Person position et al.

The external direction of self-determination is inextricably linked with the ability of a person to consciously realize his relationship with the environment at different levels. In this context, self-identification is presented to researchers as an individual-to-group path:

Group search, ie. support that provides confidence to the individual;

Self-awareness as part of a group, i.e., integration with 'us';

Dependence on the generality, solidarity in the formation of feelings of identity;

Acceptance of group ideas, values, interests, needs, goals, norms;

Forming a sense of responsibility to society.

The environment, the social environment, is a crucial factor in helping a person know who he or she is for himself or herself. However, any event, including its advantages and disadvantages, whether it belongs to one or more persons, can only be determined by determining the appropriate character point or unit of measurement. In doing so, a person compares himself with another person or his own characteristics with the characteristics of another. One can then say something about oneself, i.e., it is the identification of a category that has accepted and generalized specific characteristics common to humans [27, 123].
It is desirable that all identification decisions be based on identifying a set of personality traits such as I am human, I am a citizen, I am happy. In these judgments the theme of the reflection of personal qualities ("happy", "good", "smart", indirectly - "human", "citizen") emerges. Clearly, the counterparty that accepts these judgments has an idea of what characteristics they have in contrast to 'human', 'citizen', 'human', and 'citizen'. However, in the process of self-determination, identifying a person's characteristics is different from understanding the relationship between the 'I' and others. Recognition and approval, on the other hand, become the leading motive in human behavior. In order to pay attention, see, and hear oneself, one must define one's "I" in relation to the demands put forward by society. The incompatibility of the internal situation with the external requirements can lead to internal conflict and the individual to embarrassment, separation from the community. In this regard, a person should have a lot of social personality traits, because many other people begin to recognize $\operatorname{him}[12,74,128]$.

A person's ideas about himself, about his "I" are formed under the influence of the thoughts of others, and this includes the following three main components:

We think others will see us;

Do we think they respond to what they see ?;

How do we respond to a reaction received by others?.

This approach is based on how we interpret the thoughts and feelings of people who value us. But we can make mistakes in interpreting the opinions of others. Because self-identification 
occurs in conjunction with externally oriented assumptions, this leads the individual to be sincere. Man can hide his true feelings and give what he wants for truth or falsehood. Under the threat of flattery and hypocrisy, promotion to the top of the career ladder, dismissal, there are cases when a leader has his own point of view as a smart and fair person. But this is not true. It is human nature to hide your true thoughts and feelings under some mask. And the motivation that justifies such behavior is different. These are the fact that a person really looks better to everyone, has a good relationship with everyone, has a stable position in society. the purpose of these actions and desires is the basis of recognition in society.

The search for the 'I' cannot be limited to the interpretation of the opinion of others, for not only subjective interpretation, but a fair attitude to the behavior of others cannot be the absolute source of truth. Selfidentification, on the other hand, comes from others and then it becomes a habit. If the environment, society considered the individual ineffective and different, he soon began to trust him. However, this does not mean that the individual is entirely dependent on the point of view of the social environment. After all, it has its own mental, physiologicalbiological natural properties, and it is not easy to change it. But the more roles a person plays, the more diverse his or her repertoire can be. Therefore, a person's 'l' changes according to each of his roles $[88,102,175]$.

The formation of the human ' $\mathrm{l}$ ' can be accomplished not only through the performance of social roles, but also through the influence of reference groups that imply a real or imaginary group. Our actions, our activities, mainly depend on the actual or expected reactions of other people who belong to the reference group. But not everyone is equal to the opinion of others. For example, criminals do not take public opinion into account. They are not stopped by the public's dissatisfaction with illegal actions. Complete contradiction is a conformist behavior that accepts an individual's point of view system. He becomes a part of the individual at the expense of the appearance of the interests of the majority of the group. The influence of the group on such a person is so great that he learns the standards of the group and loses his "l", absorbed into their "we". Such behaviors are characteristic of individuals who lack self-confidence, are prone to submission, do not have their own point of view, and do not have an opinion not only in various ways, but also about their own 'I'. The complete or partial similarity of the group is usually interpreted as classical identification $[61,153,191]$.

Thus, self-determination and awareness can be seen as a way for an individual to exist as a subject of independent activity, as it is not only a manifestation of a position of value towards oneself, but also a manifestation to others.

Identification is manifested as a conformity to its subjectivity, corresponding to the world in which the person lives at the same time. Identification therefore exists in conjunction with identification as a process of establishing compatibility with others. Self-identification combines identifier and identification into a single effective mechanism that allows, on the one hand, to emphasize important features of the environment for the individual and, on the other hand, to understand the opportunities and needs that make sense to him in this 
situation. the person who predicts a person's behavior will always take a personal and social position because he or she will be focused on the world around him or herself at the same time $[55,57]$.

One of the most popular approaches that reveals the interdependence of identification and identification (as a result of selfidentification and as a mechanism of its action) is E. It is Erickson's epigenetic concept.

According to many researchers, it has the greatest value in the manifestation of selfidentification as a dynamic system. He was the first to analyze the concept of identification as a period of self-identification development. According to this concept, the relationship between identification and identification lies in their interrelationship. Identification features determine the direction of identification, thereby determining an individual's development. A person strives for harmony with himself and others. Such compatibility is a mechanism for identifying the level of identification, a mechanism for selfdetermination. This mechanism implies that it can occur as a result of an individual's selfidentification.

In the epigenetic concept, there are eight universal stages called central - maturation and psychological-social development. They are the result of an epigenetically distributed personality plan that is genetically transmitted.

E. Erickson emphasizes that with the birth of a child he is able to enter into relationships with others, in which he not only satisfies his own needs, but also manifests himself in all relationships. The child is thus manifested in the eyes of other people. This process involves how to communicate with them, how to work together. The child's ability to pay attention to the "I", to know himself and to be a person is formed.

According to the author, the crisis of personality is primarily related to the name, the second to the nation, and the third to the search for the type of classes that end with the formation of professional identity [8, 221].

The author develops the inner manifestations of the vital formation of man on the epigenetic principle, that is, man actively understands external factors, taking into account their importance for him. At each stage, the individual must constantly make choices about the universe, the world, the being, the society, and the self, which in turn determines his or her development as a person. The concept of identification is considered not only as an individual but also as a group identifier, i.e. a matter of ethnic, professional, sexual identification. The author presents a historically significant concept of understanding the world around him, which means that an individual's ability to participate maximally in socio-cultural processes is associated with minimal loss for his or her identity.

In terms of identity theory, research provides positive feedback on current issues such as loss of values and controls, resentment, extreme anxiety, loss of relationships, self-destructive behaviors, and so on, known as identity crisis. However, in some cases, the violation of identity can lead to a specific way of selfaffirmation of a person in the world society: the pathological desire to "be nothing" is noted [37]. 
Identification is a continuous process of differentiation. As the range of essential needs for man grows, it becomes more meaningful. The crisis of personality is inseparable from modern historical crises. The formation of identification depends on the existing conditions. Youth is a period in which the identification of a person has a much sharper and more radical turn than in the early stages of formation. During this period, appearance becomes a means of declaring a positive identity.

\section{REFERENCES}

1. Копылова, В.В. Методика проектной работы на уроках английского языка / В.В. Копылова. - М.: Глобус, 2007. - 96 с.

2. Крапивкина, О.А. О традициях и инновациях в методике преподавания иностранных языков / О.А. Крапивкина, Ю.О Синева // Вестник ИрГТУ. - 2013. №9 (80). С. 274-281.

3. Янкина, Н.В. Традиционные подходы и инновационные технологии в обучении студентов неязыковых специальностей иностранным языкам / Н.В. Янкина // Вестник ОГУ. - 2013. - № 2 (151). С. 300305.

4. Gavin Dudeney, Nicky Hocky. How to teach English with technology. - Harlow: Person Educated Limited, 2007. -192 p.

5. Ефремов, О.Ю. Педагогика / О.Ю. Ефремов. - СПб : Питер, 2010. - 352 с.

6. Новые педагогические и информационные технологии в системе образования: учебное пособие для студентов педагогических вузов и системы повышения квалификации педагогических кадров / под редакцией Е. С. Полат. - М. : Издательский центр «Академия», 2001. - 272 с. 47
7. Чернилевский, Д.В. Дидактические технологии в высшей школе / А.В. Чернилевский. - М. : ЮНИТИ-ДАНА, 2002. - 437 C.

8. Rahimjanovna S. M. Teaching ethics to students in technology education //Asian Journal of Multidimensional Research (AJMR). - 2020. - T. 9. - №. 3. - C. 119-122.

9. Inomidinova D. I. Impact of learning foreign languages on children development //Middle European Scientific Bulletin. - 2021. - T. 8.

10. Rahimjanovna S. M. The professional skill and competence of modern educatorpedagogue //European Journal of Research and Reflection in Educational Sciences Vol. - 2019. - T. 7. - №. 12.

11. Madinabonu Abdumannob kizi Yusufjonova. (2021). A Household Tale in Korean Folklore. INTERNATIONAL JOURNAL OF DISCOURSE ON INNOVATION, INTEGRATION AND EDUCATION, 2(2), 259-263. Retrieved from http://www.summusjournals.uz/index.ph p/ijdiie/article/view/631

12. Madinabonu Yusufjonova "Analysis of a Korean Household Fairy Tale" Published in International Journal of Trend in Scientific Research and Development (ijtsrd), ISSN: 2456-6470, Special Issue | International Research Development and Scientific Excellence in Academic Life, March 2021, pp.128-130, URL: https://www.ijtsrd.com/papers/ijtsrd3877 o.pdf

13. ЮСУФЖОНОВА M. A. K. ХУДОЖЕСТВЕННЫЕ СРЕДСТВА, ИСПОЛЬЗУЕМЫЕ В КОРЕЙСКИХ ПОСЛОВИЧНЫХ ИЗРЕЧЕНИЯХ //МОЛОДЕЖЬ И СИСТЕМНАЯ МОДЕРНИЗАЦИЯ СТРАНЫ. - 2017. - С. 5355. 
The American Journal of Social Science and Education Innovations (ISSN - 2689-100x)

Published: April 30, 2021 | Pages: 650-657

Doi : https://doi.org/10.37547/tajssei/Volume03lssue04-106

14. ЮСУФЖОНОВА М. А. К. ОСОБЕННОСТИ ПЕРЕВОДА КОРЕЙСКИХ ПОСЛОВИЦ И ПОГОВОРОК //Поколение будущего: взгляд молодых ученых. - 2016. - С. 226230.

15. ЮСУФЖОНОВА М. А. СТИЛЬ АВТОРА И ЛИТЕРАТУРНОГО ПЕРЕВОДА // Молодежь и XXI век-2017. - 2017. - С. 263265.

16. Худайбергенова 3. Н. и др. "TAHGUN HAQIDA AFSONA”, “ONDAL”,"VA “QIROL KIM SURO HAQIDA AFSONA" ASARLARIDAGI IBORALARNING LEKSIKSEMANTIK XUSUSIYATLARI //Молодой исследователь: вызовы и перспективы. 2017. - С. 196-199.

17. Madinabonu Yusufjonova "A FAIRY TALE AS A REFLECTION OF THE NATIONAL CULTURE OF THE PEOPLE" ACADEMICIA: An International Multidisciplinary Research Journal, https://saarj.com ISSN: 2249-7137 Vol. 11, Issue 3, March 2021, pp. 2533-2539 DOI: 10.5958/22497137.2021.00899.5

18. Mahfuza Rahimjanovna Shermatova "The Analysis of Examples of Classical Literature in the Primary School" Published in International Journal of Trend in Scientific Research and Development (ijtsrd), ISSN: 2456-6470, Special Issue | International Research Development and Scientific Excellence in Academic Life, March 2021, pp.137-140, URL: https://www.ijtsrd.com/papers/ijtsrd3877 4.pdf

19. Yusufjonova M. ABDULLA KAHHAR AS A SKILLFUL TRANSLATOR //European Journal of Research and Reflection in Educational Sciences Vol. - 2019. - T. 7. №. 12. M Yusufjonova - European Journal of Research and Reflection in ..., 2019 idpublications.org
20. Shermatova M. R. BOSHLANG'ICH SINF O'QUVCHILARINI TEXNOLOGIYA FANIDA AMALIY ISHLAR ORQALI HAR TOMONLAMA TARBIYALASH //Интернаука. - 2019. - №. 1-2. - С. 58-59.

21. ШЕРМАТОВА М. Р. ТЕХНОЛОГИИ ДИСТАНЦИОННОГО ОБУЧЕНИЯ //ОБРАЗОВАНИЕ. НАУКА. КАРЬЕРА. 2019. - C. 93-95.

22. Шерматова М. Р. ТЕХНОЛОГИИ И ТРУД КАК ЧАСТИ ОБРАЗОВАТЕЛЬНОЙ КУЛЬТУРЫ //Педагогика и психология в современном мире: теоретические и практические исследования. - 2018. - С. 101-104.

23. Шерматова М. Р. Особенности и методики применения информационнокоммуникативных технологий для активизации учебной деятельности в образовательном процессе на уроках в начальной школе //Молодой ученый. 2017. - №. 7. - C. 509-511.

24. ШЕРМАТОВА М. Р. ПРАКТИЧЕСКИЕ МЕТОДЫ И ПРИЕМЫ РЕАЛИЗАЦИИ ИКТ ДЛЯ АКТИВИЗАЦИИ УЧЕБНОЙ ДЕЯТЕЛЬНОСТИ МЛАДШИХ ШКОЛЬНИКОВ //МОЛОДЕЖЬ И СИСТЕМНАЯ МОДЕРНИЗАЦИЯ СТРАНЫ. - 2017. - C. 451-454.

25. Шерматова М. Р. Межличностные взаимоотношения В преподавании технологии //Молодой ученый. - 2017. №. 43. - С. 129-131. 